DOI: 10.31392/NPU-nc.series14.2019.27.14

УДК 378.011.3-051:784

Ся Цзін

\title{
Принципи організації вокальної підготовки майбутніх учителів музичного мистецтва у закладах вищої педагогічних освіти
}

\begin{abstract}
Стаття присвячена висвітленню особливостей організації та змістового наповнення вокальної підготовки майбутніх учителів музичного мистецтва в умовах професійно-спрямованого навчання у педагогічних закладах вищої освіти України. Розкрито сутність науково-теоретичного, художньовиконавського та музично-педагогічного напрямків вокальної підготовки студентів, серед яких виокремлено. Обгрунтовано доцільність впровадження у процес вокальної підготовки таких науковопедагогічних принципів іiї організації: науковості, усвідомленості, персоніфікації, інтеграції художнього і технічного компонентів, методичної спрямованості навчання. Виокремлено професійно-необхідні знання, уміння і навички, що сприяють активізації творчої самореалізації студентів, серед них навички внутрішнього слухового та виконавського інтонування; умінням аналізувати вокальні твори; знання 3 алгоритмізації засобів виконання творів; розробка та використання інноваційних методів вокальної роботи з учнями.

Ключові слова: вокальна підготовка; майбутній учитель музичного мистецтва; педагогічний принцип; методи навчання.
\end{abstract}

Актуальність дослідження. Постійний i неухильний розвиток науки, мистецтва, соціальних процесів в Україні обумовлюють потребу у підвищенні якості освітніх процесів, пошуках нових форм, способів і методів передавання знань і практичного досвіду наступним поколінням. У світлі цього актуальною сьогодні $є$ проблема удосконалення фахової, зокрема вокальної підготовки майбутніх учителів музичного мистецтва. Певного перегляду та осучаснення також потребують принципи організації вокальної підготовки студентів в умовах здобування професійної освіти у педагогічних закладах вищої освіти (ЗВО).

Проблеми вокального мистецтва і навчання досліджуються у різних аспектах: історії та теорії розвитку вокальної культури (В. Антонюк, М. Микиша, О. Стахович та ін.); психологофізіологічних та дидактичних основ навчання сольного і хорового співу (А. Менабені, Г. Стулова, Ся Цзюань, Цинь Чень, Цяо Лінь та ін.); особливостей реалізації вокальної освіти у педагогічних закладах вищої освіти, ЗВО, (Л. Василенко, С. Гмиріна, О. Петрикова, С. Ябковська, Ян Сяохань та ін.); методики музичного, вокально-хорового виховання школярів (Н. Добровольська, Л. Каменецька, В. Попов).

Метою статті $\epsilon$ обгрунтування принципів ефективної організації вокальної підготовки майбутніх учителів музичного мистецтва у педагогічних ЗВО.

Виклад основного матеріалу. Зміст навчальних дисциплін вокально-хорового циклу у системі фахової освіти спрямований на теоретичне і методичне озброєння студентів знаннями і практичними навичками роботи з власним голосовим апаратом, засобами його оптимальної організації та функціонування. Специфіка майбутньої професійної діяльності вчителя музики обумовлює особливості реалізації його вокальної підготовки, у перебігу якої формуються важливі фахові компетенції, вокально-виконавські навички й уміння, серед яких: постановка правильного вокального дихання, опанування засобів співацького звуковидобування (звукотворення), якісна дикція та артикуляція, володіння прийомів музичного голосоведіння й фразування, дотримання чистоти інтонування, відчуття ансамблю, реалізація власної манери й стилю виконання тощо. Крім того, майбутній учитель музичного мистецтва прогнозується як творча особистість, яка володіє сучасними знаннями і методами роботи 3 дитячим голосом, його розвитком та охороною.

Зазначене вимагає такої організації освітньо-виховного процесу у класі постановки голосу, на хорових дисциплінах, що забезпечує формування цілого комплексу професійнонеобхідних знань, умінь i навичок студентів для активної творчої самореалізації, 
самоудосконалення особистості фахівця засобами вокально-виконавської i музичнопедагогічної діяльності. Чільне місце у цій системі належать:

- навичкам внутрішньо-слухового та виконавського інтонування;

- умінням здійснювати художньо-педагогічний і музично-виконавський аналіз вокальних творів;

- знанням алгоритмів відбору засобів та прийомів образно-виразного, технічнодосконалого виконання творів;

- самонаціленості майбутніх фахівців на розробку та використання дієвих інноваційних методів вокальної роботи з учнями (під час проходження педагогічної виробничої практики та у подальшій професійній діяльності).

Поглиблення й систематизація вокально-теоретичних знань, формування означених умінь та навичок у студентів може відбуватись за умов: цілеспрямованого розвитку художнього компоненту свідомості майбутніх фахівців (активне музичне сприйняття, розвинене вокально-виконавське мислення, музично-слухові уявлення, пам'ять та ін.) як основи повноцінного усвідомлення усіх складових музичного змісту та індивідуально-творчого проектування образів звучання; розвитку здатності створювати оригінальні інтерпретації вокальних творів, володіння спеціальними художньо-технічними прийомами співу, вияву творчо-самостійної особистісної позиції студента в освітньому процесі, націленості на постійне самоудосконалення та самореалізацію як виконавця і педагога засобами вокального мистецтва.

3 викладеного стає зрозумілим, що вокальна підготовка майбутнього вчителя музичного мистецтва обіймає науково-теоретичний, художньо-виконавський та музично-педагогічний напрями освітньої діяльності, передбачає вирішення завдань формування важливих фахових i професійних компетентностей в галузі вокальної педагогіки, теорії та методики навчання співу, вокального виконавства. Багатовекторність і складність вирішення поставлених завдань обумовлює потребу в оновленні принципів організації вокальної підготовки майбутніх учителів музики в умовах педагогічних $3 \mathrm{BO}$.

У теорії і практиці вокальної освіти майбутніх учителів музики обгрунтуванню та розробці базових наукових положень приділяється чільна увага. Такі дослідники, як Ю. Мережко, Т. Киченко, Чжан Яньфен у своїх роботах вказують на важливість впровадження наукових підходів у систему вокальної підготовки студентів. Чжан Яньфен, наприклад, виокремлює як найбільш актуальні, комплексний, інтегративний та компетентнісний підходи. «Зазначені підходи, - зауважує автор, - вже доказали свою ефективність в теорії і практиці. Однак, в річищі нашого дослідження вони набувають дещо іншого ракурсу - спрямовують стратегію навчання на поліфукціональність вокальної підготовки студента [9, с. 145]. Ю. Мережко і Т. Киченко підкреслюють: «У зв’язку з цим особливої актуальності набуває особистісно-орієнтований підхід до навчання і виховання майбутніх фахівців, максимальному розвитку їх пізнавальної сфери. Сучасна вища школа, 3 одного боку, повинна організувати освітній процес в строгій і чіткій послідовності, а з іншого боку, вона повинна надати студентам певну свободу» [3, с. 76].

Сутність поняття принципу у дидактиці пов'язана з визначенням причинно-наслідкових зв'язків, закономірностей на основних положень щодо організації, спрямування та реалізації педагогічного (освітнього) процесу, формулювання базових вимог до цілей, завдань, змісту і методів навчання й виховання, дотримання яких забезпечує ефективність вирішення нагальних проблем.

Вокальна педагогіка виступає складовою загальної педагогіки, водночас специфіка змісту, форм і методів навчання вимагає розробки спеціальних педагогічних принципів, що відображають сутнісні характеристики співацької освіти майбутніх учителів музики. Принцип науковості в дидактиці передбачає постійний і безпосередній рух знань і способів викладання по висхідній, використання міжпредметних зв'язків, розподілу й структурування навчального матеріалу, а також застосування різних форм планування, ускладнення змісту та 
контролю у навчальній діяльності. Принцип науковості у вокальному навчанні, зокрема, обумовлює застосування передових наукових знань та емпіричних даних з галузі анатомії, фізіології, психології, мистецтвознавства для успішної постановки і розвитку голосового апарату особистості, планування і організації навчально-виховного процесу, розробки його змістових компонентів.

Актуальні наукові відомості про процеси голосоведіння, звукоутворення, розвиток та охорону співацького голосу повинні ретельно вивчатися, осмислюватися та використовуватися спеціалістами на практиці. Принцип науковості також відображає спрямованість вокально-теоретичної підготовки студентів, озброєння їх відповідними знаннями, уявленнями щодо сутності вокальних процесів і явищ (співацьке дихання, атака, способи звукоутворення, фразування, дикція та артикуляція тощо) з метою удосконалення власних вокально-виконавських умінь і використання їх у майбутній фаховій роботі 3 учнями.

Даний принцип організації вокальної підготовки майбутніх учителів музики пов'язаний $з$ принципом усвідомленості навчання. Свідоме ставлення студентів до вокально-навчальної діяльності повинно базуватись на глибокому аналізі та розумінні різних аспектів роботи голосового апарату, виявленні та розвитку усіх його художньо-виконавських можливостей.

В контексті майбутньої фахової діяльності студентам важливо вміти свідомо осмислювати, виявляти та виправляти усі наявні негативні причини і результати вокального навчання школярів. А. Менабані вказує: «Майбутньому викладачу необхідно також знання причин утворення небажаних якостей звуку (горлового, носового призвуків, сипіння) та способів їх усунення. Викриття причинно-наслідкових залежностей між явищами співацького процесу спирається на аналіз відтворюваного звуку (наслідок) і технологію голосоутворення (причина), що за своєю сутністю складає вокально-методичну підготовку майбутнього учителя» [2, с. 75]. Принцип усвідомленості у навчанні відображає таку організацію вокальної підготовки, за якої студенти націлені на активну, у тому числі самостійну діяльність, вирішення навчальних задач і проблем, досягнення особистого успіху, здійснення поточного моніторингу і контролю за власним розвитком і навчанням. Отже, даний принцип включає цілеспрямоване і свідоме ставлення студентів до освітнього процесу, активність проявів особистісних вольових якостей та націленість на досягнення високих результатів у вокальній підготовці.

У контексті розуміння неповторної унікальності художньо-виконавських здібностей та індивідуальних можливостей кожного студента важливого значення набуває дотримання принципу персоніфікації навчання. Необхідність реалізації цього принципу обумовлюється особливостями природного (фізіолого-анатомічного, психологічного) та спеціальномузичного розвитку суб'єкта вокального навчання, а відтак - потребою у різноманітних методах і прийомах роботи з кожним окремим індивідуумом. Фактично даний принцип враховує загальні, вікові та суто індивідуальні параметри особистісного розвитку студентів, враховує особливості життєвого, співацького та творчо-виконавського досвіду, інтелектуальні, емоційні, діяльнісні характеристики психіки, що впливають на процес навчання.

Принцип персоніфікації спрямовує процес навчання вокалу на пошуки варіативнозмінюваних складових його організації та методів педагогічного впливу. Положення про важливість персоніфікації навчання набуває особливого значення саме у плані постановки голосу, адже «на передній план виходить необхідність урахування особливостей звучання голосу i голосотворення кожного учня, які обумовлюються будовою i роботою його голосового апарату», - зазнає А. Менабені [2, с. 76]. Реалізація принципу персоніфікації навчання вимагає від суб'єктів освітнього процесу: творчо-діалогової взаємодії для розробки та реалізації спеціальних методів і прийомів вокального розвитку; націленості на оновлення існуючих та створення особистісно-орієнтованих технологій індивідуальної роботи з кожним 
учнем, студентом, колективом; здійснення постійного педагогічного спостереження за навчальною і виконавською діяльністю, творчим успіхами підочних та ін..

Ефективність вокальної підготовки майбутніх учителів музичного мистецтва, на наш погляд, залежить від дотримання принципу інтеграції художнього і технічного компонентів у навчанні. Цей спеціальний для музичної педагогіки принцип націлює студентів на досягнення високого рівня виконавської майстерності на основі створення цілісних художньо-виразних образів звучання, донесення їх до слухачів за допомогою майстернотехнічного володіння засобами вокального виконавства. Реалізація цього принципу в освітньому процесі можлива за умови знаходження певного співвідношення балансу між художніми і технічно-складними задачами, що висуваються перед студентами на кожному занятті, репетиції, при опрацюванні різних музичних творів. Дане положення також $\epsilon$ актуальним для музикантів різного профілю, людей творчих, мистецьких професій.

Означений принцип відображає сутнісні процесуальні та функціональні взаємозв'язки у вокальній діяльності, а також цілісну неподільність художньо-образного і технічновиконавського компонентів звучання. Навчання співу спрямовує роботу всього організму, голосового апарату людини у певному напрямку, пристосовуючи їх до реалізації спеціальних функцій, творчо-виконавських завдань. 3 одного боку, вокальна діяльність постійно контролюється музичним слухом співака, його свідомістю та підсвідомими (інтуїтивними) процесами психіки. 3 іншого, виразність, емоційність та художня переконливість звучання залежать від володіння технічними прийомами звуковидобування, сформованості вокальновиконавських умінь і навичок.

Г. Стулова в контексті дидактичних основ вокального навчання наголошує на тому, що «задача технічного розвитку співацького голосу... повинна постійно підпорядковуватись художнім цілям. Вокальний слух педагога і самих учнів керує процесами формування вокальної техніки останніх. Звідси виникає необхідність виховання образного мислення, творчої уяви, художнього смаку та ін..» [7, с. 54]. Реалізація цього принципу сприяє інтеграції художньо-стильових, технічно-змістових, емоційно-смислових уявлень та вокальновиконавських умінь співака в єдиний образ-концепцію звучання.

Виразна інтерпретація музичного змісту вимагає від вокаліста володіння комплексом необхідних співацьких навичок, умінь застосовувати потрібні для донесення характеру і настроїв твору техніки фразування, тембрального забарвлення, динамічного співвідношення музичного смислу. Таким чином, принцип інтеграції художнього і технічного компонентів у вокальному навчанні підтверджує цілісно-неподільну природу творчо-виконавського процесу i орієнтує студентів на досягнення високого рівня вокальної майстерності, розкриття власного особистісного потенціалу.

Для майбутньої професійної діяльності вчителя музики особливого значення набуває принции методичної спрямованості навчання. Система вокального навчання базується на поєднанні загальнодидактичних і спеціальних методів і прийомів навчання. Проте вокальна підготовка майбутніх учителів музичного мистецтва передбачає озброєння їх методиками розвитку співацького голосу учнів різного віку. Отже, у фаховій підготовці студентів вокальне навчання значною мірою спрямоване не тільки на формування практичних навичок співу, а й опанування методики роботи з голосовим апаратом школярів.

Теорія і практика вокальної освіти містить напрацьований багатий методичний досвід у галузі розвитку співацького голосу. Серед перевірених часом традиційних методів вокального навчання й виховання виокремлюються пояснювальний, ілюстративний, наочнодемонстративний, імітаційний, аналітичний, репродуктивний, асоціативний та інші. Останнім часом увагу спеціалістів привертають такі сучасні методи вокального навчання, як проективні, інтерактивні, діалогові методи, співтворчості, активізації музично-слухового сприйняття, емоційного стимулювання, цілісного охоплення музичного змісту, м'язового контролю та ін. 
При використанні різних методів вокального навчання потрібно враховувати, що найбільш дієвим способом формування інтересу до співу залишається емоційно-виразне, привабливе звучання голосу вчителя. Завдяки цьому в учнів виникає цілий комплекс слухових відчуттів, емоційних вражень, смислових уявлень про характер і зміст музичного твору, у них з'являється бажання вчитися, досягати певних успіхів. У роботі з дітьми вчитель повинен демонструвати таку манеру співу, яка б максимально вигідно представляла усі художні якості голосу і наближалась до характеру звучання дитячих голосів. Таким чином, принцип методичної спрямованості відображає потребу у методичній оснащеності майбутніх фахівців сучасними засобами і прийомами педагогічної роботи (володіння методичними компетентностями) та реалізації творчого підходу до організації навчально-виховного процесу на уроках музичного мистецтва.

Висновки. Отже, у матеріалах даної статті обгрунтовано і розкрито напрямки і сутнісні характеристики вокальної підготовки майбутніх учителів музичного мистецтва. Доведено, що в умовах навчання студентів у педагогічних закладах вищої освіти за обраною спеціальністю найбільш доцільними принципами організації вокальної підготовки виступають принципи: науковості, усвідомленості, персоніфікації, інтеграції художнього і технічного компонентів та методичної спрямованості навчання.

\section{Література}

1. Антонюк В. Г. Вокальна педагогіка (сольний спів) : Підручник. К.: ЗАТ «Віпол», 2007. - 174 с.

2. Менабени А. Г. Методика обучения сольному пению : учеб. пособ. для студ. пед. ин-тов. М. : Просвещение, 1987. - 95 с.

3. Мережкко Ю.В. Формування навичок самостійної роботи майбутніх учителів музичного мистецтва на заняттях з постановки голосу Науковий часопис НПУ імені М.П. Драгоманова. Серія 14. Теорія і методика мистецької освіти. - Вип. 26 : зб. наук. праць К. : Вид-во НПУ, 2019. - С. 75-82.

4. Микиша М. В. Практичні основи вокального мистецтва: [літ. виклад М. Головащенка]. - 2-е вид. - К.: Муз. Україна, 1985. - 80 с.

5. Можайкіна Н. С. Методика викладання вокалу. Хрестоматія : Навч. посіб. К.: Вид-во Ліра, 2016. $-216 \mathrm{c}$.

6. Стахевич О. Г. Основи вокальної педагогіки. Ч. 1. Природно-наукові теорії сольного співу. Курс лекцій : Навч. посібник для студ. дир-хор. фак. та пед. вузів Х. - Суми : ХДАК - СумДПУ ім. А. С. Макаренка, 2002. -92 с.

7. Стулова Г. П. Дидактические основы обучения пению : учеб. Пособие. М.: МГПИ, 1988. $69 \mathrm{c}$.

8. Халабузарь П. В. Методика музыкального воспитания : Учеб. пособие М.: Музыка, 1989. 175 c., нот.

9. Чжан Яньфен. Педагогічні умови формування вокальної художньо-виконавської підготовки майбутніх учителів музики / Чжан Яньфен // Науковий часопис НПУ імені М. П. Драгоманова. Серія 14. Теорія і методика мистецької освіти : зб. наук. праць / Матеріали IV Міжнародної науковопрактичної конференції «Гуманістичні орієнтири мистецької освіти», 27-29 квітня 2011 року. - Вип. 11 (16). - К.: Вид-во НПУ, 2011. - С. 145-148.

10. Ябковська С. П. Формування вокальних навичок у співаків-початківців Луцьк : ПВД «Твердиня», 2009. - 78 с.

Про автора:

Ся Цзін, кандидат педагогічних наук, лектор, Хуанганський нормальний університет, вокальний факультет (430013, Ухань, провінція Хубей, Китай); ORCID: 0000-0002-4115-989X, e-mail: 147709970@qq.com

\section{The principles of vocal training methodology for prospective music art teachers in higher teacher training institutions}

Xia Jing

The article under consideration reveals the specifics of training methodology implementation in the corresponding teaching conditions; it also covers the issue of arrangement and content of prospective Music Art teacher's vocal training in higher teacher training institutions. The appropriateness of implementing 
several science and pedagogical principles in vocal training process was justified, such as: the principle of scientific character; the one of consciousness; the personification one; the one of integrating artistic and technical components; the one of methodological focus of learning.

Taking the necessity of upgrading the teaching/learning process quality, as well as seeking new forms and techniques of transferring the training information and practical experience to the students into consideration, there appears an issue of perfecting prospective Music Art teacher's professional, i.e. vocal skills. The principles of student's vocal training methodology under the conditions of obtaining professional education in higher teacher training institutions require reconsidering; thus, our goal to attain is justifying the principles of effective vocal training methodology for prospective Music Art teachers within their learning process.

The key characteristics of Music Art teacher's prospective professional activity presuppose the specifics of his/her vocal skills implementation, shaping the core professional competences (vocal inhale training; obtaining singing phonation facilities; proficient elocution and articulation; the grasp of music voice-leading and phrasing methods; intonation clarity, etc.). The prospective Music Art teacher is to acquire up-to-date knowledge and techniques of shaping a child's singing voice and protecting it.

The expert's vocal training presupposes solving the issues within vocal pedagogy, singing teaching theory and methodology domain. The difficulty of the solution predetermines the need for updating the principles of vocal training methodology for prospective experts in higher institutions.

The principle of scientific character in student's vocal training presupposes scientific knowledge implementation in various sciences' domain (Anatomy, Physiology, Psychology, Art Study) for the efficient work of their vocal apparatus. The principle of scientific character also reflects the focus of student's vocal and theoretical skills, as well as deepening the knowledge of the essence of vocal phenomena, in order to perfect their own vocal and performance skills and to implement them in their further work with young learners.

The principle of consciousness reflects the students' determination to work actively and autonomously; to solve learning issues; to achieve their personal success; to implement independent monitoring of their development and training results. This principle includes motivation, the student's conscious attitude to the learning process, activeness and personal will-power; the prospective experts' intention to attain top results in their vocal training.

Awareness of every student's uniqueness in terms of their artistic and performance skills and individual abilities causes following the personification principle of learning. Implementation of this principle is predetermined by the distinctness of physiological, anatomic, psychological and special musical development of each vocal training individual. This explains the necessity of diversifying the teaching methodology for each learner. Thus, the principle involves considering individual features of the student's personal development; singing practice characteristics; intellectual, psychic emotional specifics that influence their learning process and its effectiveness accumulatively; focuses on seeking variable and modifiable constituents of its management and pedagogical impact methodology for their vocal training.

The effectiveness of prospective Music Art teacher's vocal training depends on following the principle of integrating artistic and technical components in the teaching process. This principle, which is specific for Music teaching, is targeted at attaining the top level of performance artistry in terms of revealing artistic expression of music compositions to the audience via technical skills grasp of vocal performance facilities. The principle under consideration reflects the consistency of artistic and figurative, technical and performance components of voice production. Vocal activity is constantly being under control of the singer's tuneful ear, as well as of psychic conscious and even subconscious intuitive processes. Furthermore, expressiveness, emotionality and artistic persuasiveness of phonation depend directly on the grasp of sound production technical methods.

The principle of methodological focus of learning acquires specific significance for the Music Art teacher's further professional practice; the learners' vocal training presupposes obtaining the methodologies of shaping their singing voice and various-aged pupils' voices. Thus, the student's vocal training is chiefly aimed at shaping the practical singing skills, as well as at the grasp of teaching methodology for perfecting the young learners' voice apparatus.

Keywords: vocal training; prospective Music Art teacher; teacher pedagogical principle; teaching methodology. 


\section{References}

1. Antonyuk V. G. (2007).Vokalna pedagogika (solnij spiv) : Pidruchnik / V.G. Antonyuk. - K. : ZAT «Vipol»,. - 174 s. [in Ukrainian]

2. Menabeni A. G. (1987). Metodika obucheniya solnomu peniyu : Ucheb. posobie dlya studentov ped. in-tov. M. : Prosveshenie, 95 s. [in Russian]

3. Merezhkko Yu. V. (2019). Formuvannya navichok samostijnoyi roboti majbutnih uchiteliv muzichnogo mistectva na zanyattyah $\mathrm{z}$ postanovki golosu. Naukovij chasopis NPU imeni M.P. Dragomanova. Seriya 14. Teoriya i metodika misteckoyi osviti. - Vip. 26 : zb. nauk. prac. K. : Vid-vo NPU, S. 75-82. [in Ukrainian]

4. Mikisha M.V. (1985). Praktichni osnovi vokalnogo mistectva / M.V. Mikisha : [lit. viklad M. Golovashenka]. - 2-e vid. - K.: Muz. Ukrayina, 80 s. [in Ukrainian]

5. Mozhajkina N. S.( 2016). Metodika vikladannya vokalu. Hrestomatiya : Navch. posib. K. : Vid-vo Lira, 216 s. [in Ukrainian]

6. Stahevich O.G.(2002). Osnovi vokalnoyi pedagogiki. Ch. 1. Prirodno-naukovi teoriyi solnogo spivu. Kurs lekcij : Navch. posibnik dlya stud. dir-hor. fak. ta ped. vuziv. - Sumi : HDAK - SumDPU im. A. S. Makarenka, 92 s. [in Ukrainian]

7. Stulova G. P. (1988). Didakticheskie osnovy obucheniya peniyu : Ucheb. posobie. M. : MGPI, 69 s. [in Russian]

8. Halabuzar P. V. (1989). Metodika muzykalnogo vospitaniya : ucheb. posobie. M. : Muzyka, 175 s. [in Russian]

9. Chzhan Yanfen (2011). Pedagogichni umovi formuvannya vokalnoyi hudozhno-vikonavskoyi pidgotovki majbutnih uchiteliv muziki. Naukovij chasopis NPU imeni M. P. Dragomanova. Seriya 14. Teoriya i metodika misteckoyi osviti : zb. nauk. prac. Vip. 11 (16). - K. : Vid-vo NPU, S. 145-148. [in Ukrainian]

10. Yabkovska S.P. (2009). Formuvannya vokalnih navichok u spivakiv-pochatkivciv Luck : PVD «Tverdinya», 78 s. [in Ukrainian]

About the author:

Xia Jing, Candidate of Pedagogical Sciences (Ph.D.), lecturer, vocal department, HuangGang Normal University (430013, Wuhan, Hubei, China); ORCID: 0000-0002-4115-989X, e-mail: 147709970@qq.com 